\title{
An overview of the utilisation of microalgae biomass derived from nutrient recycling of wet market wastewater and slaughterhouse wastewater
}

\author{
A. Y. Maizatul • Radin Maya Saphira Radin Mohamed • Adel A. Al-Gheethi • \\ M. K. Amir Hashim
}

Received: 21 October 2016/ Accepted: 3 May 2017/Published online: 24 May 2017

(C) The Author(s) 2017. This article is an open access publication

\begin{abstract}
Microalgae have high nutritional values for aquatic organisms compared to fish meal, because microalgae cells are rich in proteins, lipids, and carbohydrates. However, the high cost for the commercial production of microalgae biomass using fresh water or artificial media limits its use as fish feed. Few studies have investigated the potential of wet market wastewater and slaughterhouse wastewater for the production of microalgae biomass. Hence, this study aims to highlight the potential of these types of wastewater as an alternative superior medium for microalgae biomass as they contain high levels of nutrients required for microalgae growth. This paper focuses on the benefits of microalgae biomass produced during the phycoremediation of wet market wastewater and slaughterhouse wastewater as fish feed. The extraction techniques for lipids and proteins as well as the studies conducted on the use of microalgae biomass as fish feed were reviewed. The results showed that microalgae biomass can be used as fish feed due to feed utilisation efficiency, physiological activity, increased resistance for several diseases, improved stress response, and improved protein retention.
\end{abstract}

Keywords Nutrients $\cdot$ Extraction $\cdot$ Fish growth $\cdot$ Lipids $\cdot$ Proteins $\cdot$ Fish feed

$\begin{array}{ll}\text { Abbreviations } \\ \text { GHG } & \text { Greenhouse gas } \\ \text { BOD } & \text { Biochemical oxygen demand } \\ \text { COD } & \text { Chemical oxygen demand } \\ \text { TSS } & \text { Total suspended solids } \\ \text { DO } & \text { Dissolved oxygen } \\ \text { HPLC } & \text { High-performance liquid chromatography } \\ \text { GC-MS } & \text { Gas chromatography-mass spectrometry } \\ \text { CBB-G } & \text { Coomasie brilliant blue-G250 dye } \\ \text { BSA } & \text { Bovine serum albumin } \\ \text { TCA } & \text { Trichloroacetic acid } \\ \text { NIR } & \text { Near infrared spectroscopy } \\ \text { SFE } & \text { Supercritical fluid extraction method }\end{array}$

A. Y. Maizatul · Radin Maya Saphira Radin Mohamed $(\bowtie) \cdot$ A. A. Al-Gheethi · M. K. A. Hashim Department of Water and Environmental Engineering, Faculty of Civil and Environmental Engineering, Micro-pollution Research Centre (MPRC), Universiti Tun Hussein Onn Malaysia, Batu Pahat, 86400 Parit Raja, Johor, Malaysia e-mail: maya@uthm.edu.my; alisaeed@uthm.edu.my 


\section{Introduction}

Microalgae are aquatic organisms with different sizes ranging between $1 \mu \mathrm{m}$ and $2 \mathrm{~mm}$ (Baharuddin et al. 2016). They are photosynthetic organisms which utilise light and carbon dioxide to create biomass (Sirakov et al. 2015). However, their growth relies on environmental factors such as nutrient quality and quantity, light, $\mathrm{pH}$, turbulence, salinity, and temperature (Arkronrat et al. 2016). Microalgae play a vital role in food production and the purification of contaminated environment water by assimilating nutrients from water and wastewater (Ramaraj et al. 2015; Baharuddin et al. 2016). They play important roles in the food chain, since they represent the main food for rotifers, cladocerans, fish, and shrimp larvae due to their high nutritional value which includes lipid, protein, carotene, vitamins, carbohydrates, and other essential minerals for the development of aquaculture organisms (Hakalin et al. 2014; Baharuddin et al. 2016). Among several species of microalgae, Chlorella sp., Scenedesmus sp., and Spirulina sp. are common in the production of animal feed supplements, fertilizers, health skin products, and other applications (Pulz and Gross 2004).

Furthermore, microalgae represent an alternative energy resource to non-renewable energy coming from fossil fuels (Makareviciene et al. 2011; Gour et al. 2016). The importance of microalgae as an energy resource lies in the world's high energy demand which leads to the depletion of traditional energy resources such as fossil fuels which are associated with the release of harmful gases such as nitrogen oxide, carbon dioxide, carbon monoxide, and sulphur oxide into the atmosphere (Ren 2014). The accumulation of these gases in the atmosphere can lead to health problems, the acid rain phenomenon, global warming, and depletion of the ozone layer (Rulong et al. 2012). It has been found that the total annual anthropogenic greenhouse gas (GHG) emission during the period from 1970 to 2010 was $1.3 \%$, and has increased to $2.2 \%$ in the period between 2000 and 2010 (IPCC 2014).

Interest in microalgae as biofuel feedstock can be associated with several factors such as increasing world oil prices, declining oil supplies from fossil fuels, and global warming from excessive carbon emission of vehicles (Griffiths et al. 2011). Microalgae are a good source for biofuel production due to the high content of lipids in the microalgae cells. For instance, lipids represent $22 \%$ of the total biomass yield of Scenedesmus sp. which are generated in the production media with low nutrient requirements (Zhang and Hong 2014). Microalgae have a higher lipid content compared to different terrestrial crops due to their simple unicellular structure and high photosynthetic efficiency for higher oil production (Griffiths et al. 2011). Table 1 below demonstrates oil yield from microalgae compared to other terrestrial plants. It can be observed that the microalgae oil yield ranges from 4.7 to $14 \mathrm{~L} / \mathrm{m}^{2} /$ year which is higher compared to palm oil yield $\left(0.54 \mathrm{~L} / \mathrm{m}^{2} /\right.$ year), Jatropha (0.19 L/m²/year), sunflower $\left(0.09 \mathrm{~L} / \mathrm{m}^{2} /\right.$ year), and soya $\left(0.04 \mathrm{~L} / \mathrm{m}^{2} /\right.$ year) (Sheehan et al. 1998 ; Sazdanoff 2006; Mata et al. 2010).

Microalgae can grow rapidly and are potentially useful for biofuel production. Microalgae are rich in lipids and carbohydrates. They also contain excellent properties for biofuels such as biodiesel, bioethanol, and biomethane (Singh and Gu 2010). The previous studies had identified Botryococcus sp. which store long chain hydrocarbons in $50 \%$ of its dry biomass (Hannon et al. 2010). Besides that, microalgae cultivation for biofuel production used minimal land compared to other terrestrial plants such as canola, Jatropha, corn, and soybean but yields high oil content. According to Singh and $\mathrm{Gu}$ (2010), biodiesel yield from microalgae was $58,700 \mathrm{~L} \mathrm{ha}^{1}$ for microalgae containing only $30 \%$ oil by weight compared with $1190 \mathrm{~L} \mathrm{ha}^{1}$ for Canola and $1892 \mathrm{~L} \mathrm{ha}^{1}$ for Jatropha. Microalgae are able to produce biofuel from biomass and also remediate nutrients from wastewater. These characteristics make microalgae a potential crop which can be used to produce costcompetitive biofuels (Hannon et al. 2010).

Table 1 Production of oil from crops compared to algae

\begin{tabular}{lll}
\hline Types of crops & Oil yield $\left(\mathrm{L} / \mathrm{m}^{2} /\right.$ year $)$ & References \\
\hline Microalgae & $4.7-14$ & Sheehan et al. (1998) \\
Palm & 0.54 & Mata et al. (2010) \\
Jatropha & 0.19 & Sazdanoff (2006) \\
Sunflower & 0.09 & \\
Soya & 0.04 & \\
\hline
\end{tabular}


Microalgae as a source of energy can be applied for the production of hydrogen gas, methane, and biogas (Golueke et al. 1957). Microalgae species with high oil content used for biodiesel production are Chlorophyta and Bacillariophyta (Griffiths et al. 2011). The previous studies have revealed that microalgae are able to produce biodiesel amounting to 6283 gallons/acre compared to corn (18 gallons/acre) and soybeans (48 gallons/acre), respectively (Chisti 2007; Kumar et al. 2015). Microalgae lipid comprises of triacylglycerol (TAG), phospholipid, and glycolipid. In general, the lipid in microalgae is stored in the form of TAG. Fast growing species have relatively low lipid production, but stress conditions may trigger lipid production up to $60 \%$ of cell dry weight (Griffiths et al. 2011). Jena et al. (2012) indicated that the lipid productivity of Scenedesmus sp. is $24.66 \mathrm{mg} / \mathrm{L} /$ day with $0.9976 \mathrm{~g} / \mathrm{L}$ of biomass during the stationary growth phase. This value is higher than that recorded for Chlorococcum sp. and Chlorella sp. which are $12.44 \mathrm{vs} .16 .11 \mathrm{mg} / \mathrm{L} / \mathrm{day}$ of productively and $0.9922 \mathrm{vs} .0 .9933 \mathrm{~g} / \mathrm{L}$ of biomass yield, respectively. However, it has to be mentioned that the reported data about the production of biofuel from microalgae species are still based on the lab scale experiments, while reported data on the commercialisation of biofuel from microalgae biomass are still limited (Xin et al. 2011; Kumar et al. 2015). This might be due to the high production cost and the absence of effective methods to convert biomass into biofuel at a low operational cost (Chen et al. 2012).

Furthermore, one of the ways which microalgae biomass can be obtained is through the phycoremediation process of wastewater (Sethupathy et al. 2015). Phycoremediation is a specific term to represent the process of using microalgae to treat wastewater by the assimilation of nutrients such as total phosphorus (TP), total nitrogen (TN), and total organic carbon (TOC) from wastewater (Al-Darmaki et al. 2012; Jais et al. 2017). In contrast, phytoremediation is most common term used to represent a similar process conducted by plants. The efficiency of this process lies in its dual role which refers to the treatment of wastewater and the production of biomass, respectively (Pahazri et al. 2016). It has been found that the microalgae in the phycoremediation process have the capacity between 70 and $90 \%$ to remove nitrate, sulphate, and phosphate (Nandeshwar and Satpute 2014). The phycoremediation process is associated with the high production of microalgae biomass which has numerous applications (Atiku et al. 2016). Moreover, the utilisation of microalgae biomass as fish feed might be more applicable without more extractions and preparation processes, because microalgae represent natural fish food in water (Brown 2002; Guedes and Malcata 2012; Skarka 2012; Baharuddin et al. 2016).

The current review deals with the technical feasibility of phycoremediation for the treatment of wet market wastewater and slaughterhouse wastewater, the production of microalgae biomass, and the improvement of wastewater characteristics before the final disposal into the environment. The main aim of this article is to provide a summary of recent information concerning the use of microalgae biomass as fish feed. To do so, an overview of the phycoremediation process and factors affecting biomass production are presented. The authors recommend that the utilisation of microalgae biomass for aquaculture food depends on the nutrition values and the extraction process of the lipids and proteins from the biomass yield instead of the microalgae species. Moreover, the reader is strongly encouraged to refer to the original research papers for information on experimental conditions.

\section{Characteristics of wet market wastewater and slaughterhouse wastewater}

Increased urbanisation and industrialisation has placed increased water quality and quantity stress in many countries such as Malaysia (Chan 2006; Lee et al. 2015). Indeed, the main problem lies in the quantities of wastewater generated from different human activities which are discharged into natural bodies of water. These practices reduce access to clean water and increase the pollution levels of natural waters. Therefore, the management and treatment of wastewater are some of the initial steps to limit environmental pollution and maintain the river basin capacity (Lee et al. 2015).

Wastewater is a general term which refers to different types of wastewater such as industrial wastewater, hospital wastewater, domestic wastewater, public market wastewater, slaughterhouse wastewater, and greywater. The level of organic matter for each type of wastewater is different. Therefore, the physical, chemical, and biological characteristics such as biochemical oxygen demand (BOD), chemical oxygen demand (COD), high total suspended solids (TSS), heavy metals, $\mathrm{pH}$, temperature and complex mixture of fats, carbohydrates, and proteins differ (Rajakumar et al. 2011). For instance, the high concentrations of BOD and COD as well as 
Table 2 Physicochemical characteristics of wastewater before and after phycoremediation by Scenedesmus sp. (Ajayan et al. 2016)

\begin{tabular}{lll}
\hline Characteristics & Before & After \\
\hline Colour & Light brown & Colourless \\
Odour & Odourless & Odourless \\
Temperature $\left({ }^{\circ} \mathrm{C}\right)$ & 26.8 & NR \\
TSS & 5.6 & 8.3 \\
TDS & 1753 & 1134 \\
TS & 4528 & 2768 \\
BOD & 326 & 212 \\
COD & 872 & 548 \\
DO & 1.60 & 11.2 \\
Nitrate & 49 & 21.7 \\
Phosphorus & 3.90 & 0.10 \\
Chromium & 12.8 & 5.40 \\
Copper & 4.90 & 1.00 \\
Lead & 3.2 & 1.91 \\
Zinc & 7.4 & 2.52 \\
\hline All
\end{tabular}

All values are in $\mathrm{mg} / \mathrm{L}$ except for those otherwise mentioned

infectious agents in sewage are associated with high content of organic matter. Hence, the selection of the treatment process depends on the wastewater composition. The major requirement in wastewater treatment is the removal of nutrients which would reduce microbial loads in the wastewater to acceptable limits prior to discharge and reuse (Al-Gheethi et al. 2013). Ajayan et al. (2016) studied the phycoremediation of wastewater by Scenedesmus sp. and the composition of wastewater was found to have improved in terms of colour, TDS, TS, BOD, COD, and DO (Table 2). The colour of wastewater changed from light brown to colourless, whereas the TDS value decreased from 1753 to $1134 \mathrm{mg} / \mathrm{L}$. Then, the BOD and COD values reduced from 326 to $212 \mathrm{mg} / \mathrm{L}$ and 872 to $548 \mathrm{mg} / \mathrm{L}$, respectively. Other than that, dissolved oxygen (DO) increased from 1.60 to $11.2 \mathrm{mg} / \mathrm{L}$. Nutrient and heavy metals composition in tannery wastewater reduced slightly. The nitrate and phosphorus content reduced from 49 to $21.7 \mathrm{mg} / \mathrm{L}$ and 3.90 to $0.10 \mathrm{mg} / \mathrm{L}$, respectively. On the other hand, chromium, copper, lead, and zinc reduced by about 50\% after phycoremediation (Ajayan et al. 2016).

The discharge of wastewater with high organic matter contributes to the reduction of dissolved oxygen (DO) in water. Thus, fish and other aquatic biota cannot survive in water with a low DO content (Mohamed et al. 2016). Besides, wastewater has high nutrient levels such as phosphorus and nitrogen (including ammonia) that can lead to eutrophication which can be toxic to aquatic organisms. In addition, eutrophication also depletes oxygen levels, destroys nursery grounds and leads to the extinction of certain species (AlGheethi et al. 2015).

In terms of nutrients, it has been reported that wet market wastewater and slaughterhouse wastewater are very rich in nitrogen and phosphorus (Jais et al. 2015). Slaughterhouse wastewater originates from the washing process of meat, poultry, and fish, while wet market wastewater includes wastewater generated from the washing of fruit and vegetables in public markets (Jais et al. 2017). These types of wastewaters are characterised by the presence of high levels of nitrogen, phosphorus, COD, BOD, suspended solids, fats, oils, and grease compared to residential wastewater (Santos and Robbins 2004). The differences between chemical and physical characteristics of slaughterhouse wastewater and wet market wastewater are illustrated in Table 3. It can be noted that the $\mathrm{pH}$ of wet market wastewater ranged from 5.6 to 7.5 (Zulkifli et al. 2011; Omar et al. 2016), while the $\mathrm{pH}$ of slaughterhouse wastewater ranged from $\mathrm{pH} 6.5$ and 7.6 (Rajakumar et al. 2011; Bustillo-Lecompte and Mehrvar 2015). Moreover, the slaughterhouse wastewater has higher turbidity compared to wet market wastewater (275 vs. $74.9 \mathrm{mg} / \mathrm{L}$, respectively) (Jais et al. 2015; Bustillo-Lecompte and Mehrvar 2015). In terms of BOD and COD concentrations, it was reported that these parameters in the slaughterhouse wastewater are more than the parameters in wet market wastewater. According to $\mathrm{Li}$ et al. (2008), BOD and COD in the slaughterhouse wastewater ranged between 750 and $2895 \pm 585$ and between 
Table 3 Characteristic of wet market and slaughterhouse wastewater

\begin{tabular}{|c|c|c|c|c|c|c|c|c|}
\hline \multirow[t]{2}{*}{ Parameter* } & \multicolumn{4}{|c|}{ Wet market wastewater } & \multicolumn{4}{|c|}{ Slaughterhouse wastewater } \\
\hline & $\begin{array}{l}\text { Jais et al. } \\
(2015)\end{array}$ & $\begin{array}{l}\text { Zulkifli } \\
\text { et al. } \\
\text { (2011) }\end{array}$ & $\begin{array}{l}\text { Noori } \\
\text { et al. } \\
(2016)\end{array}$ & $\begin{array}{l}\text { Omar } \\
\text { et al. } \\
(2016)\end{array}$ & $\begin{array}{l}\text { Li et al. } \\
\text { (2008) }\end{array}$ & $\begin{array}{l}\text { Bustillo- } \\
\text { Lecompte et al. } \\
\text { (2015) }\end{array}$ & $\begin{array}{l}\text { Budiyono } \\
\text { et al. (2011) }\end{array}$ & $\begin{array}{l}\text { Rajakumar } \\
\text { et al. (2011) }\end{array}$ \\
\hline $\mathrm{pH}$ & $5.9-6.1$ & $5.6-5.8$ & $5.5-6.5$ & $7.0-7.5$ & NR & 6.5 & $7.19 \pm 0.06$ & $7-7.6$ \\
\hline Turbidity & $57.1-74.9$ & N/A & NR & NR & NR & 275 & NR & NR \\
\hline BOD & $85.39-92.62$ & $71-122$ & NR & NR & $2895 \pm 585$ & 2649 & $1873 \pm 421$ & $750-1890$ \\
\hline COD & $448.2-464.19$ & $381-560$ & $1150 \pm 5$ & 1708 & $4672 \pm 952$ & 5577 & $3756 \pm 687$ & $3000-4800$ \\
\hline TSS & $131.9-133.7$ & $60-122$ & NR & 140 & $1403 \pm 596$ & 3092 & $1171 \pm 311$ & $300-950$ \\
\hline $\mathrm{SO}_{4}$ & $32.3 \pm 0.78$ & NR & NR & NR & NR & NR & NR & NR \\
\hline $\mathrm{Cl}$ & $32 \pm 0.69$ & NR & NR & NR & NR & NR & NR & NR \\
\hline $\mathrm{TN}$ & $36.9 \pm 0.5$ & $30.3-37.3$ & NR & 288 & $356 \pm 46$ & 156 & $212 \pm 106$ & $16-165$ \\
\hline $\mathrm{TP}$ & $1.61 \pm 0.13$ & $0-22.2$ & NR & 66 & $29 \pm 10$ & 42.8 & NR & $16-32$ \\
\hline TOC & $118.67 \pm 2.89$ & NR & NR & NR & NR & 862 & NR & NR \\
\hline $\begin{array}{l}\text { Oil and } \\
\text { grease }\end{array}$ & $5.22 \pm 0.07$ & $13-43$ & NR & NR & NR & NR & NR & $800-1385$ \\
\hline $\mathrm{TS}$ & NR & NR & NR & NR & NR & NR & NR & $400-3900$ \\
\hline TVS & NR & NR & NR & NR & NR & NR & NR & $800-1800$ \\
\hline VFA & NR & NR & NR & NR & NR & NR & NR & $250-540$ \\
\hline $\begin{array}{l}\text { Alkalinity } \\
\qquad\left(\mathrm{CaCO}_{3}\right)\end{array}$ & NR & NR & NR & NR & NR & NR & NR & $600-1340$ \\
\hline TKN & NR & NR & NR & NR & NR & NR & NR & $109-325$ \\
\hline Protein & NR & NR & $265 \pm 12$ & NR & NR & NR & $1303 \pm 653$ & $580-1000$ \\
\hline
\end{tabular}

* All parameters are expressed as $\mathrm{mg} \mathrm{L}^{-1}$ except for Turbidity (NTU) and $\mathrm{pH}$. Biochemical oxygen demand (BOD); Chemical Oxygen Demand (COD); high Total suspended solids (TSS); Total Organic Carbon (TOC); Total nitrogen (TN); Total phosphorus (TP); volatile fatty acids (VFA); TKN-Total Kjeldahl Nitrogen (TKN); Sulphate $\left(\mathrm{SO}_{4}\right)$; Total Chlorine $(\mathrm{Cl})$; Total Volatile Solids (TVS); Total Solids (TS); NR (Non-reported)

3000 and $5577 \mathrm{mg} / \mathrm{L}$, respectively, whereas they ranged between 71 and $122 \mathrm{mg} / \mathrm{L}$ and between 381 and $1708 \mathrm{mg} / \mathrm{L}$, respectively, in the wet market wastewater. The high concentrations of BOD and COD in slaughterhouse wastewater might be due to the presence of blood and complex mixtures of fats, proteins, and fibres which contribute to the increase of organic matter (Rajakumar et al. 2011; Kundu et al. 2013). The high concentrations of nutrients in slaughterhouse wastewater might provide a more suitable environment for microalgae growth. Nevertheless, the similarity between slaughterhouse wastewater and wet market wastewater lies in the level of nutrients which is within the range required for microalgae growth. Therefore, both types of wastewaters contribute to the contamination of natural water systems and eutrophication (Atiku et al. 2016; Pahazri et al. 2016).

The increasing production and associated consumption of meat and poultry had increased the discharge of wastewater. Between 2005 and 2013, the consumption rate increased by more than $60 \%$ for beef which increased from 138,980 to 201,556 tons, whereas the consumption rate for chicken increased by more than $50 \%$ which rose from 785,660 to 1,390,660 tons. The huge quantities of these foods are correlated with huge amounts of wastewater generated. Consequently, the discharge of these wastes into the environment lead to the heavy pollution of natural waters and the occurrence of eutrophication (Bello and Oyedemi 2009; Kundu et al.2013).

\section{Phycoremediation of wet market and slaughterhouse wastewater and the production of microalgae biomass}

Several treatment technologies are used for the treatment of wastewater (Table 4). The proper treatment technologies of slaughterhouse wastewater have the potential to produce high-quality wastewater that meets the international standards for the disposal process. Anaerobic treatment in upflow anaerobic sludge blanket 
Table 4 Different technologies used to treat slaughterhouse wastewater

\begin{tabular}{|c|c|c|c|}
\hline Technology & $\begin{array}{l}\text { Characteristic of slaughterhouse } \\
\text { wastewater }\end{array}$ & Efficiency & References \\
\hline $\begin{array}{l}\text { Anaerobic treatment in up } \\
\text { flow anaerobic sludge } \\
\text { blanket (UASB) and } \\
\text { aerobic filter }\end{array}$ & $\begin{array}{l}\text { High organic content with average COD } \\
\text { of } 8000 \mathrm{mg} / \mathrm{L} \text { with } 70 \% \text { proteins. TSS } \\
\text { represent } 15 \text { and } 30 \% \text { of COD }\end{array}$ & COD removal is $90 \%$ & $\begin{array}{l}\text { Ruiz et al. } \\
\quad(1997)\end{array}$ \\
\hline $\begin{array}{l}\text { Anaerobic sequencing } \\
\text { batch reactors }\end{array}$ & $\begin{array}{l}\text { Total chemical oxygen demand (TCOD) } \\
\text { ranged } 6908 \text { to } 11500 \mathrm{mg} / \mathrm{L} \text {. } \\
\text { Approximately } 50 \% \text { in the form of } \\
\text { suspended solids (SS) }\end{array}$ & $\begin{array}{l}\text { COD reduction is } 90 \% \text { within } 2 \text { days } \\
\text { of hydraulic retention time }\end{array}$ & $\begin{array}{l}\text { Masse and } \\
\quad \text { Masse (2000) }\end{array}$ \\
\hline $\begin{array}{l}\text { Moving bed sequencing } \\
\text { batch reactor }\end{array}$ & $\begin{array}{l}\text { COD, BOD, and suspended solids in the } \\
\text { range of } 4700-8000 \mathrm{mg} / \mathrm{L}, \\
\text { respectively }\end{array}$ & $\begin{array}{l}\text { COD and BOD removal efficiency is } \\
\text { greater than } 80 \text { and } 90 \% \text {, } \\
\text { respectively. TKN removal } \\
\text { efficiency of } 86-93 \%\end{array}$ & $\begin{array}{l}\text { Sombatsompop } \\
\text { et al. (2011) }\end{array}$ \\
\hline $\begin{array}{l}\text { Fixed bed sequencing } \\
\text { batch reactor (FBSBR) }\end{array}$ & $\begin{array}{l}\text { The wastewater has COD loadings in the } \\
\text { range of } 0.5-1.5 \mathrm{~kg} \mathrm{COD} / \mathrm{m}^{3} \text { per day }\end{array}$ & $\begin{array}{l}\text { COD, TN, and Phosphorus removal } \\
\text { efficiency at range } 90-96 \% \text {, } \\
60-88 \% \text { and } 76-90 \% \text {, respectively }\end{array}$ & $\begin{array}{l}\text { Rahimi et al. } \\
\text { (2011) }\end{array}$ \\
\hline $\begin{array}{l}\text { Chemical coagulation and } \\
\text { electrocoagulation } \\
\text { techniques }\end{array}$ & $\begin{array}{l}\mathrm{COD} \text { and } \mathrm{BOD}_{5} \text { of raw wastewater in the } \\
\text { range of } 5817 \pm 473 \text { and } \\
2543 \pm 362 \mathrm{mg} / \mathrm{L}\end{array}$ & $\begin{array}{l}\text { Removal of COD and } \mathrm{BOD}_{5} \text { more } \\
\text { than } 99 \% \text { is obtained by adding } \\
100 \mathrm{mg} / \mathrm{L} \mathrm{PACl} \text { and applied } 40 \mathrm{~V} \\
\text { voltage }\end{array}$ & $\begin{array}{l}\text { Bazrafshan } \\
\text { et al. (2012) }\end{array}$ \\
\hline
\end{tabular}

(UASB) and aerobic filter methods exhibited high efficiency in removing COD of up to $90 \%$ (Ruiz et al. 1997). The moving bed sequencing batch reactor had been reported as an effective method for COD, BOD, and TKN removal at 80, 90, and 86-93\%, respectively (Sombatsompop et al. 2011). Rahimi et al. (2011) studied the treatment of slaughterhouse wastewater with a fixed bed sequencing batch reactor (FBSBR). The study showed that COD, TN, and TP removal efficiency ranged between 90 and $96 \%, 60$ and $88 \%$, and 76 and $90 \%$, respectively. The electrocoagulation and chemical coagulation techniques for slaughterhouse wastewater treatment had successfully removed COD and $\mathrm{BOD}_{5}$ by more than $99 \%$ after adding $100 \mathrm{mg} / \mathrm{L} \mathrm{PACl}$ and applying $40 \mathrm{~V}$ voltage (Bazrafshan et al. 2012).

Most technologies such as anaerobic treatment as well as chemical coagulation and electrocoagulation techniques are effective for the reduction of the main parameters of wastewater (Sombatsompop et al. 2011; Bazrafshan et al. 2012). However, the cost of the treatment technology should be considered especially in developing countries. Besides, these technologies are designed in a centralised system in which a sewerage network is needed to collect the wastewater generated from different wet markets and slaughterhouses into the central treatment plant and this represents the main challenge in developing countries. Therefore, to reduce the huge quantities of untreated wastewater discharged into the environment, an individual system fixed at each wet market and slaughterhouse location might contribute significantly to the requirements. Phycoremediation might be an alternative technology, because it is cheaper and more effective for removing nutrients compared to other methods (Kwarciak-Kozłowska et al. 2014; Sethupathy et al. 2015; Wurochekke et al. 2016). The phycoremediation process is a microalgae-based technology where microalgae are inoculated into wastewater which acts a culture medium. The microalgae cell growth in the wastewater leads to the removal of nutrients via the assimilation mechanism (Kwarciak-Kozłowska et al. 2014; Satpal and Khambete 2016). Besides, phycoremediation of wastewater using microalgae produces large amounts of biomass which have recently been used for several applications such as animal and fish feeds, fertilizers, as well as biofuel (Al-Darmaki et al. 2012).

Many microalgae species have been used in the phycoremediation process of wastewater. Scenedesmus sp. is one of the most common microalgae used, because it has high potential to tolerate acidic eutrophic water conditions and a wide range of temperature for growth $\left(20-36^{\circ} \mathrm{C}\right)$. Therefore, the lipid and carbohydrate contents in their cells are normally high (Xin et al. 2011; Cassidy 2011; Baharuddin et al. 2016). Microalgae have the ability to grow in an environment with $\mathrm{pH}$ ranging from 7 to 9.5 at which the microalgae exhibit a higher efficiency in capturing $\mathrm{CO}_{2}$ in the atmosphere which then induces the high production of biomass (Liu et al. 2005; Zang et al. 2011). However, chlorophyll content in microalgae decreases when the $\mathrm{pH}$ value 
increases from $\mathrm{pH} 8.5$ to 9.5 . The decrease in chlorophyll content is associated with low microalgae activity and the low removal of nutrients from wastewater. Rai et al. (2015) revealed that the maximum production of the biomass was recorded at $\mathrm{pH} 7\left(1.3 \mathrm{~g} \mathrm{~L}^{-1}\right)$, while the lowest production was noted at $\mathrm{pH} 8\left(0.9 \mathrm{~g} \mathrm{~L}^{-1}\right)$. Therefore, the $\mathrm{pH}$ of wastewater during the phycoremediation process needs to be within the optimal $\mathrm{pH}$ range. This can be achieved using a continuous operating system where new wastewater is added to renew microalgae growth and to provide more nutrients. Moreover, $\mathrm{pH}$ factor is one of the many factors, which has more influence on microalgae growth. For example, temperature is a vital factor which has a linear relationship with microalgae growth, because it is able to modify growth rates and bio-product productivity (Huang et al. 2008; Ras et al. 2013; Minhas et al. 2016). Effects of temperature include cellular chemical composition, rate of photosynthesis, nutrient uptake, $\mathrm{CO}_{2}$ fixation, and respiration intensity (Tan et al. 2009). Scenedesmus sp. grows within a temperature ranging between 10 to $40{ }^{\circ} \mathrm{C}$. To counteract temperature fluctuation, the microalgae cell will undergo the shrinking process (Ras et al. 2013). Spirulina plantesis exhibited maximum growth at $35{ }^{\circ} \mathrm{C}\left(0.091\right.$ doubling/day), while it dropped to 0.041 doubling/day at $40{ }^{\circ} \mathrm{C}$. The variations in the surrounding temperature of the microalgae production medium might also affect the chlorophyll and protein content (Cassidy 2011; Xin et al. 2011). At high temperature, the chlorophyll and protein content in the microalgae cell is reduced, but the carotenoids, saccharides (sugars), and lipids will increase (Cassidy 2011). Microalgae growth rates are inversely proportional to the cell size. The cell sizes increases at low temperature but shrinks at high temperature (Chen et al. 2012). At a lower temperature $\left(4^{\circ} \mathrm{C}\right.$ or below), photosynthesis is completely inhibited (Takemura et al. 1985).

Another factor which affects microalgae growth and cell content is light (Kumar et al. 2011; Pérez-Pazos and Fernández-Izquierdo 2011). The variation in light intensity and photoperiod might influence lipid production in the microalgae cells, because lipoid production is associated with carbon content (Pérez-Pazos and Fernández-Izquierdo 2011). Microalgae use carbon at low light intensity to synthesise amino acids, whereas under saturated light, the microalgae cells produce sugars, lipids, and starch (Pérez-Pazos and FernándezIzquierdo 2011). Rai et al. (2015) estimated biomass and lipid production under different light and dark periods. The study revealed that the maximum biomass $(0.54 \mathrm{~g} / \mathrm{L})$ and lipid yield $(0.079 \mathrm{~g} / \mathrm{L})$ were recorded when microalgae were exposed to light for $24 \mathrm{~h}$, whereas the minimum production amounted to 0.25 and $0.04 \mathrm{~g} / \mathrm{L}$ for biomass and lipids, respectively, with $8 \mathrm{~h}$ of incubation under light. However, excessive light exposure can cause light prohibition in microalgae (Ren 2014). Kumar et al. (2011) found that the maximum light intensity to produce carotenoid in Spirulina platensis was 3500 1x, while the highest amount of biomass was obtained at $2000 \mathrm{~lx}(0.71 \mathrm{~g} / \mathrm{L})$.

In general, wastewater contains a high level of nutrients (nitrogen, phosphorus, and carbon) and organic matter which act as elements to increase microalgae biomass (Riano et al. 2016). The availability of nutrients in wastewater such as nitrogen can improve the production of biomass. Riano et al. (2016) indicated that C.sorokinianabiomass produced 3.0-4.5\% dry matter from nitrogen uptakes, whereas the nitrogen content in biomass cells ranged from 27 to $40 \%$. The nitrogen levels in wastewater affect microalgae lipid production and growth rates by $1-10 \%$ (Minhas et al. 2016) as high concentrations of nitrogen might increase the quantity of microalgae biomass. In contrast, the production of lipid and carbohydrates increases when there is nitrogen deficiency. Li et al. (2008) reported that Neochloris sp. and Nannochloropsis sp. had increased lipid yield under conditions of nitrogen deficiency, while Tetraselmis sp. and Scenedesmus sp. had an increased production of carbohydrates under similar conditions (Minhas et al. 2016). Hence, to optimise the production of biomass alongside with high lipid yields, microalgae should be cultivated in nitrogen rich conditions for high production of biomass yield and then transferred to low nitrogen conditions for lipid production.

Carbon source also has an effect on microalgae biomass. Makareviciene et al. (2011) reported that the biomass yield of Chlorella sp. and Scenedesmus sp. increased simultaneously with the increase of $\mathrm{CO}_{2}$ concentrations. The study revealed that at a carbon dioxide concentration of $24 \%$, the growth of microalgae reached a maximum biomass of 0.2 and $0.12 \mathrm{~g} / \mathrm{L}$, respectively, for Chlorella $\mathrm{sp}$. and Scenedesmus sp.

Phosphorous essential for the production of algal biomass is needed in quantities of approximately $0.03-0.06 \%$ in the medium to sustain algal growth (Hannon et al. 2010). Phosphorus is present in wastewater as orthophosphate $\left(\mathrm{PO}_{4}{ }^{3-}\right)$ which is optimal for the production of microalgae biomass (Solovchenko et al. 2016). Rasala and Mayfield (2015) reported that phosphorus uptake by microalgae from wastewater is stored in cells in the form of polyphosphate. Mulbry et al. (2008) revealed that microalgae have a high efficiency in removing phosphorus from wastewater as much as 70 to $90 \%$. Microalgae take up inorganic phosphate from 
wastewater via luxury uptake in which algae cells absorb much more phosphate from water than what is necessary for growth (Solovchenko et al. 2016). Microalgae growth and phosphate uptake from wastewater are linearly proportional to biomass yield. However, the phosphorus uptake from wastewater can be limited by factors such as light (self-shading), carbon dioxide, and oxygen levels. The main pollutant which is normally used by microalgae is phosphorus. Phosphorus is released into the waterways from farm manure, fertilizers, detergents, industrial effluents, human waste, and decaying plants (Sen et al. 2013). Phosphorus is essential for the synthesis of nucleic acids, phospholipids, and phosphate esters, and microalgae can obtain phosphorus from wastewater to stimulate growth due to their role in metabolic and anabolic pathways (Pahazri et al. 2016). Jais et al. (2017) stated that dried microalgae use phosphorus to build cells via an anabolic pathway. Phosphorus levels in wastewater should be considered, because it may limit microalgae growth (Pahazri et al. 2016; Jais et al. 2017). Orthophosphate is the most preferred form of phosphorus for microalgae growth as it easily binds to iron and action for extracellular hydrolytic enzymes. Thus, wastewater with a high concentration of phosphorus and a low amount of iron can be a good medium for microalgae growth.

\section{Extraction and determination of nutritional values of microalgae biomass}

Numerous analytical techniques including chromatography, capillary electrophoresis, infrared spectroscopy, light scattering detection, and nuclear magnetic resonance spectroscopy have been used for measuring the concentration of carbohydrates in microalgae biomass yields. The easiest, low-cost method for the determination of the concentration of carbohydrates is using the calorimetric method. This method depends on the reaction between a reagent (Phenol) and hydrolysed carbohydrates which further develops a colour complex detected using an electromagnetic spectrum. However, this method is less accurate for determining carbohydrates in very low concentrations. Besides, the chemical reagents can cause serious health problems such as being corrosive to skin, eyes, and some may even affect the respiratory system (Albalasmeh et al. 2013). Highperformance liquid chromatography (HPLC) is highly efficient in the determination of carbohydrates in microalgae biomass. HPLC is rapid, specific, sensitive, and precise. Gas chromatography-mass spectrometry (GC-MS) is another technique used for measuring carbohydrates in biomass yield. However, in this method, the carbohydrates should be extracted before the test. Carbohydrates can also be determined using the capillary electrophoresis method after being extracted with borates. Carbohydrates are separated in the gel based on size when voltage goes through it. The smaller the size of the particles, the further away it gets in the gel across the electric field.

Extraction of protein from microalgae is crucial to increase protein efficiency and there are several methods for microalgae extraction such as bead beating, sonication, potter homogenisation, and microwaves to disrupt the microalgae cell wall. Schwenzfeier et al. (2011) used bead milling for the extraction of proteins from Tetraselmis sp. The results revealed that the protein yield increased from 36 to $64 \%$. Barbarino and Lourenco (2005) and Murphy et al. (2000) both indicated that the extraction of protein using potter homogeniser and sonication increased the yield of protein compared to non-grinding microalgae biomass. Lee et al. (2010) claimed that the microwaves method is efficient for extracting protein from Botryococcus sp. C. vulgaris and Scenedesmus sp.

Protein content in microalgae biomass can be quantified using the calorimetric method (Bradford 1976; Lowry et al. 1951; Smith et al. 1985) which depends on nitrogen elements (Lopez et al. 2010). Bovine serum albumin (BSA) is the most common substance which is used as a protein standard for calibration curves in the spectrophotometer (Barbarino and Lourenco 2005). The reagent substrate used in the calorimetric method is coomasie brilliant blue-G250 dye (CBB-G) which binds to amino acid residues on the microalgae strain (Bradford 1976). However, CBB-G yields a low concentration of protein compared to Lowry assay (1951) which depends on the use of Trichloroacetic acid (TCA) for protein recovery on microalgae pellets (Murphy et al. 2000). In addition, the previous studies conducted on the determination of proteins based on the usage of CBB-G in the calorimetric method in Porphyridium sp., Phaeodactylum sp, and Dunaliella sp. demonstrated that the protein yield from biomass may differ due to the interference of several substances such as Phenol (Murphy et al. 2000). Therefore, TCA is more accurate for the determination of proteins, since the function of TCA is to coagulate with amino acids (Rajamani and Hilda 1987). Proteins are formed by linkages of amino acids (Craig 2009). There are ten essential amino acids that cannot be synthesised by fish. These amino acids 
include methionine, arginine, threonine, tryptophan, histidine, isoleucine, lysine, leucine, valine, and phenylalanine, and should be supplied through the diet (Craig 2009). The fish feed prepared using plant (soybean meal) protein are typically low in methionine; therefore, extra methionine must be added to soybean meal-based diets to promote optimal growth and health (Ajani et al. 2016). Thus, it is important to know and match the protein requirements and the amino acid requirements of each of the fish species.

Rodríguez et al. (1997) studied the amino acids found in two species of microalgae (Chlorella pyrenoisdosa and Chlamydomonasreinhardii) via high-performance liquid chromatography (HPLC) using pre-column fluorescence derivatisation. The study revealed that the predominant amino acids found in Chlorella pyrenoisdosa were arginine, alanine, lysine, serine, and glutamic acid, whereas in $C$. reinhardii, the predominant amino acids were alanine, arginine, leucine, lysine, serine, and glutamic acid. The high content of amino acids may be explained by their roles as a nitrogen reserve and for tricarboxylic acid metabolism (Rodríguez et al. 1997). Derrien et al. (1998) determined free amino acids from five species of microalgae which are commonly used in aquaculture such as Tetraselmis suecica, Skeletonema costatum, Chaetoceros calcitrans, Thalassiosira sp., and Isochrisis galbana. The microalgae species belonging to S. costatum and C.calcitrans had aspartic acid as a dominant amino acid and about $10 \%$ of isoleucine. Thalassiosira sp.is rich in serine, glutamic acid, and tyrosine. I. galbana showed a completely different composition in free amino acids, with $67.9 \%$ of tyrosine followed by serine and arginine. Different cultivation conditions such as temperature, light, $\mathrm{pH}$, and mixing can affect the amino acid composition of microalgae for aquaculture feed (Derrien et al. 1998).

Other than protein and amino acids, lipids are also an important component in microalgae biomass. There are several methods for lipid extraction from microalgae (Table 5). It appeared that electroporation and the pressurized solvent extraction method for lipid extraction had the highest efficiency compared to other methods such as organic solvent, bead beating, and osmotic shock method (Kumar et al. 2015). Besides efficiency rating, the energy consumption, cost, and environmental effects should also be considered. Organic solvent, pressurized solvent extraction, and bead beating methods have high energy requirement in terms of extraction, whereas electroporation and osmotic shock had less energy consumption. Usually low energy consumption methods are cost-effective methods. For instance, osmotic shock requires less energy and low operation cost. Lipid extraction is performed through the hexane Soxhlet extraction and Bligh-Dyer method of 2:1 methanol-chloroform (Bligh and Dyer 1959; Zhang and Hong 2014). However, different microalgae strains show different efficiencies in terms of lipid extraction where the Soxhlet method is normally used for high-quality lipids (fatty acid and triglycerides), whereas the Bligh-Dryer method is normally used for extracting total lipids from microalgae.

The Soxhlet extraction method (AOAC 1995) is the quantification of lipids using solid-liquid extraction in the Soxhlet apparatus. In this method, the solvent is boiled, condensed and passed through microalgae tissue several times for lipid extraction. Then, the solvent is evaporated before the fat is weighed. However, the Soxhlet method needs a large amount of solvent and it is time-consuming. Besides that, lipids can also be determined using near infrared spectroscopy (NIR) at specific wavelengths. The carbonyl group in the ester linkage of lipids is capable of absorbing infrared energy. The method is non-destructive and the microalgae biomass sample can be used for contaminant analysis. However, NIR is not widely used for lipid determination. King (2002) had demonstrated the use of the supercritical fluid extraction method (SEF) to extract lipids. The samples are extracted with liquid carbon dioxide (solvent) before the evaporation and weighing

Table 5 Different lipid extraction methods: cost and energy efficiency (Kumar et al. 2015)

\begin{tabular}{|c|c|c|c|c|}
\hline Method & $\begin{array}{l}\text { Efficiency } \\
\text { rating }\end{array}$ & Cost & $\begin{array}{l}\text { Energy } \\
\text { requirement }\end{array}$ & Remarks \\
\hline Organic solvent & Moderate & High & Intensive & Health and Environmental Hazard \\
\hline $\begin{array}{l}\text { Pressurized solvent } \\
\text { extraction }\end{array}$ & High & High & Intensive & Health and Environmental Hazard \\
\hline Bead beating & Moderate & Cost-effective & Intensive & Difficult to scale up \\
\hline Electroporation & Very high & $\begin{array}{l}\text { Initial investment high cost then } \\
\text { operate lower cost }\end{array}$ & Less energy & $\begin{array}{l}\text { Appears promising but need to study } \\
\text { for pilot scale }\end{array}$ \\
\hline Osmotic shock & $\begin{array}{l}\text { Moderate- } \\
\text { high }\end{array}$ & Low-cost method & Less energy & Longer treatment time $>48 \mathrm{~h}$ \\
\hline
\end{tabular}


process. The SFE method is effective for lipid quantification and no organic solvent is needed for analysis, but it is an expensive method. The lipid extraction methods described by Folch et al. (1957) and Bligh and Dyer (1959) are used as standard procedures for total lipid recovery. Folch et al. (1957) described a method known as a single-step extraction method for lipid recovery. The method used chloroform: methanol (2:1) to extract lipid before washing it with $0.9 \%$ potassium chloride $(\mathrm{KCl})$. Bligh and Dryer method (1959) consists of a three-step solvent extraction method for lipid quantification. The method used methanol: chloroform, followed by chloroform and water extraction. The lipid is determined by evaporation of the solvent. Both of these methods are simple and well established, but the Bligh and Dryer (1959) method can analyse microalgae biomass directly without pre-drying treatment.

Cho et al. (2012) examined various solvents to extract lipid from microalgae. The solvents include acetone, hexane, hexane:ether $(1: 1, \mathrm{v} / \mathrm{v})$, ethanol, and chloroform:methanol $(2: 1, \mathrm{v} / \mathrm{v})$. The results revealed that chloroform:methanol was the best solvent for lipid extraction with an efficiency of $15 \%(\mathrm{w} / \mathrm{w})$ compared to $1.3,2.1,4.5$, and $11.1 \%(\mathrm{w} / \mathrm{w})$ of lipid obtained using acetone, hexane, hexane:ether $(1: 1, \mathrm{v} / \mathrm{v})$, and $70 \%$ ethanol, respectively. However, using chemical solvents for the quantification of lipid has several disadvantages related to their high toxicity towards humans and the surrounding environment (Zhang and Hong 2014). In terms of the lipid contents in microalgae cells, it has been found that Scenedesmus sp. has the highest lipid content compared to Chlorococcum sp. and Chlorella sp. with $24 \%$ lipid per dry weight during the early stationary phase (Jena et al. 2012). Dayananda et al. (2010) reported that the lipid content from Botryococcus sp. extracted using chloroform: methanol (1:2) reached $14 \%$.

In lipid extraction, fatty acid methyl ester (FAME) analysis is used to determine docosahexaenoic acid (DHA) and eicosapentaenoic acid (EPA) which are essential for fish growth. Fatty acids such as eicosapentaenoic acid (EPA: 20:5n-3) and docosahexaenoic acid (DHA: 22:6n-3) cannot be synthesised by freshwater fish and must be supplied through diet. Both of these fatty acids are necessary for metabolic functions and cellular membrane components. Prommuak et al. (2012) investigated the fatty acid profile of Chlorella vulgaris using GC analysis. The most abundant FAME was methyl linoleate, methyl palmitate, and a small amount of methyl oleate and stearate. These FAMEs were reported to be the most common components in crops (Prommuak et al. 2012). Microalgae are the primary producers of polyunsaturated fatty acids (PUFAs). Pieber et al. (2012) extracted PUFA from Nannochloropsisoculata using the pressurized fluid extraction technique (PFE) and accelerated solvent extraction (ASE) using different solvents. $N$. oculata was rich in eicosapentaenoic acid (EPA) when extracted via ethanol extraction (36 \pm 4 mass $\%$ ) compared to low yields from $n$-hexane extraction $(6.1 \pm 0.3$ mass $\%)$. The EPA yield of $3.7 \pm 0.1$ mass $\%$ with the use of ethanol indicates that EPA production from $N$. oculata is economically beneficial.

\section{Microalgae biomass quality as fish feed}

Aquaculture refers to the production of aquatic organisms such as shrimp, fish, crustacean, and shellfish in cages. Globally, aquaculture has developed rapidly to reduce the gap between market demand and supply. Fish stock worldwide has been declining due to overfishing, but the demand for food has been steadily increasing (Focardi et al. 2005). Therefore, aquaculture development is an alternative way to fulfil the demand for seafood worldwide. The sustainability of the aquaculture industry depends on several factors such as wild stock and fisheries production (Focardi et al. 2005). The aquaculture industry relies on juvenile fish being caught from the wild to supply stock rather than using hatcheries which cause the bycatch of other species. It is reported that 15-20 billion fry of other species such as finfish and shellfish in Honduras, Indian, and Bangladesh has been left aside after accidentally being caught from the wild (Islam et al. 2004; Sarkar and Bhattacharya 2003).

The increasing demand for seafood has led to the intensive development of aquaculture industries all over the world (Gao et al. 2016). However, the development of the aquaculture industry leads to increasing feeding cost and wastewater problems caused by fish food residue and fish faeces (Roy et al. 2011; Gao et al. 2016). High nutrient content such as carbon, phosphorus, and nitrogen from uneaten fish food and faeces leads to eutrophication and the outbreak of diseases. However, the improvement of feed quality can help reduce nutrient pollutants in water columns (Focardi et al. 2005; Mente et al. 2006). High level of nutrients in water columns from fish farming may create favourable conditions for the growth of dinoflagellates (Mente et al. 
2006) and lead to harmful algal blooms (HAB) which can deplete oxygen level, reduce light penetration, and release toxins associated with paralytic shellfish poisoning. The previous studies by Joseph et al. (1988) and Michels et al. (2014) had turned problems into opportunities in which integrated aquaculture systems were used to convert waste into algal biomass. The cultivation of microalgae in aquaculture wastewater has been reported where the microalgae may help eliminate excess nutrients from wastewater and produce biomass which can be converted into potential bio-products (Joseph et al. 1988; Michels et al. 2014).

The high feeding cost of wild catch for the production of fish oil and fish meal had caused a decline in the aquaculture industry. Besides that, fishmeal is expensive (Abdulrahman and Ameen 2014). Thus, the replacement of fish meal using microalgae as a protein source may help to resolve problems existing within the aquaculture industry. Microalgae incur low cost compared to fish meal (Abdulrahman and Ameen 2014). Microalgae biomass has been used widely to substitute the traditional fish meal due to their positive effects on fish growth, feeding efficiency, nutrient composition, and fish body development (Roy et al. 2011). Microalgae also have high nutritional values such as protein, carbohydrates, lipid, and trace elements such as vitamins which are considered important for aquaculture (Guedes and Malcata 2012, Skarka 2012). Microalgae are used as a live feed for all growth stages of bivalve molluscs such as oysters, scallops, clams and mussels, crustaceans, and some fish species (Brown 2002). The nutritional value of microalgae is due to the presence of essential macro and micronutrients in their cells (Guedes and Malcata 2012). It has been reported that microalgae cells have $30-40 \%$ of protein, 10-20\% of lipid content, and 5-15\% of carbohydrates (Brown 2002). Therefore, microalgae have high potential to be used as an alternative protein source for fish feed (Sirakov et al. 2015). The composition of microalgae biomass in terms of nutritional value: protein, carbohydrates, and lipid, is illustrated in Table 6. Based on the data presented in the table, it can be seen that Spirulina maxima has the highest protein percentage (60-71\%), followed by C. vulgaris (51-58\%) and S. obliquus (50-56\%). In contrast, Dunaliellasalina has the highest carbohydrate content (32\%) followed by S.dimorphus (21-52\%) and Tetraselmismaculata (15\%). S.dimorphus has the highest lipid composition (16-40\%) followed by B.braunii (Tartiel 2005; Um and Kim 2009).

Several studies have been conducted on microalgae in fish diets. The utilisation of microalgae as fish feed has induced the growth rate of fish, increased feeding utilisation efficiency and physiological activity, increased the resistance for several diseases, improved stress response, and improved protein retention (Sirakov et al. 2015). Algae meal has been also recommended as a good feed complement for counteracting intestinal inflammation produced by soybean meal and is used as a binding agent for aqua feed palletisation (Hashim and Saat 1992; Grammes et al. 2013). Microalgae have been proven as an alternative for fish feed which can reduce cost but, at the same time, provide high protein content to the consumer (Sirakov et al. 2015).

Microalgae biomass used as fish meal for improving fish growth rate is related mainly to the high content of carbohydrates, lipids, and proteins. The carbohydrates in microalgae are available in the form of starch which is easily metabolised by fish (Choix et al. 2012). Carbohydrates represent the main energy source for animals

Table 6 Composition of microalgae biomass in term of nutritional value: protein, carbohydrate, and lipid (Tartiel 2005; Um and Kim 2009)

\begin{tabular}{llll}
\hline Microalgae species & Protein & Carbohydrate & Lipid \\
\hline Botryococcus braunii & 40 & 2 & 33 \\
Chlorella sp. & 46.7 & 11.6 & 14.8 \\
C. vulgaris & $51-58$ & $12-17$ & $14-22$ \\
Dunaliella Salina & 57 & 32 & 6 \\
D. bioculata & 49 & 4 & 8 \\
Scenedesmus sp. & 52.3 & 10.06 & 12.2 \\
S. dimorphus & $8-18$ & $21-52$ & $16-40$ \\
S. obliquus & $50-56$ & $10-17$ & $12-14$ \\
Spirulina maxima & $60-71$ & $13-16$ & $6-7$ \\
S. platensis & $42-63$ & $8-14$ & $4-9$ \\
Tetraselmis maculata & 52 & 15 & 3 \\
\hline
\end{tabular}


including fish. Besides that, the production of astaxanthin from microalgae has been used to enhance colouration for salmon and rainbow trout (Skarka 2012). Common species which produce astaxanthin are Haematococcus sp., Chlorella sp., Chlorococcum sp, and Xanthophyllomyces sp.

The development of the aquaculture industry in Malaysia requires the consumption of fish meal and fish oil. However, fish meal and fish oil are highly dependent on wild catch fisheries as a source of fish food. The production of aqua feeds is essential as a source of dietary lipids (fish oil) and proteins (fish meal). Dietary protein levels for different species vary from 30 to $57 \%$, and 5 to $8 \%$ for dietary lipid levels (Mente et al. 2006). Other critical problems related to the wild catch of fisheries include high cost and limited stock. To reduce the pressure on the demand for fishmeal and fish oil, it needs to move towards sustainably produced plant-based feeds. Table 7 shows the trend of fishmeal and fish oil consumption in the aquaculture industry for three products: salmonid, shrimp, and marine finfish. It is clear that there was an increase in fishmeal and fish oil consumption which was 343,000 tonnes of fishmeal (1992) to 789,000 tonnes fishmeal for salmonid, 232,000 tonnes to 670,000 tonnes fishmeal for shrimp, and 180,000 tonnes to 590,000 tonnes for marine finfish (Tacon et al. 2006).

The substitution of fishmeal with proteins from plants is becoming a necessity, because high-quality plant proteins are readily available. It also involves low-cost fluctuation and sustainable production (Mente et al. 2006). Currently, the replacement of fishmeal is constrained by anti-nutritional factors that cause adverse effects on fish health. For instance, carbohydrate content in soya was found to be less suitable for rainbow trouts (Oncorhynchus mykiss) as it can cause prolonged postprandial hyperglycaemia (Panserat and Kaushik 2002). Therefore, in-depth research is needed to understand the dietary requirements of fish for the development of diets that can replace fishmeal as the major source of dietary protein for farmed fish

Microalgae is seen as a fish feed alternative due to their low production cost, rapid growth rates, abundance in stock, and high nutritional value. It was found that microalgae biomass have successfully been used as fish feed for Tilapia (Oreochromisniloticus) and provided sufficient protein to enhance fish weight (Badwy et al. 2008; Vizcaíno et al. 2014; Norambuena et al. 2015).

Roy et al. (2011) examined the use of microalgae biomass as fish feed. The study formulated algae mix feeds and the feed contained $10.32 \%$ of crude lipid, $24.29 \mathrm{~kJ} / \mathrm{g}$ of gross energy, $7.08 \%$ of calcium, and $1.46 \%$ of phosphorus. Feeding fish (Oreochromis sp.) with a mixed algal diet had increased the survival rates of fish by $99.7 \%$ compared to the conventional feeds $(96.5 \%)$. It has also increased fish body weight from 1.85 to $7.96 \mathrm{~g}(303.27 \%)$ compared to 1.85-6.5 g for the conventional feed. Abdulrahman and Ameen (2014) had formulated a diet for carps (Carpinuscarpio) using Spirulina sp. in five different dried microalgae compositions: $0 \%$ (T1), 5\% (T2), 10\% (T3), 15\% (T4), and 20\% (T5). The study was conducted to determine the weight gain and survival rates of carp feed on Spirulina sp. The results found that carps fed with $10 \%$ of dried Spirulina sp. (T3) had a higher body weight (16.593 g) compared to other replacements T1, T2, T4, and T5 which resulted in body weight measuring $8.375,12.663,13.000$, and $15.033 \mathrm{~g}$, respectively. Besides that, the carp showed a higher survival rate for T2 $(92.857 \%)$ and T4 $(92.857 \%)$.

Radhakrishna et al. (2015) investigated the effects of replacement for 25, 50, 75, and $100 \%$ of C. vulgaris biomass on the growth performance, energy utilisation, and digestive enzyme of freshwater prawn during the post-larvae stage (Macrobrachiumrosenbergii). From the study, it was reported that 50\% of fishmeal replaced with $C$. vulgaris enhanced the growth performance $(1.252 \pm 0.04 \mathrm{~g} /$ day), survival rate $(93.33 \pm 2.50 \%)$, and feeding rate efficiency $(2.54 \pm 0.22 \%)$. It was concluded that $C$. vulgaris was easily absorbed and digested by animals. Microalgae applications as aquaculture feed are presented in Table 8 which summarised microalgae potential as aquaculture feed. The highest growth rate of Nile Tilapia had been reported by Attalla and Mikhail

Table 7 Estimated use of fishmeal and fish oil for three types of aquaculture products (Adapted from Tacon et al. 2006)

\begin{tabular}{llrrr}
\hline Aquaculture product & 1992 (tonnes) & & \multicolumn{2}{c}{2003 (tonnes) } \\
\cline { 2 - 3 } & Fishmeal & Fish oil & Fishmeal & Fish oil \\
\hline Salmonid & 343,000 & 107,700 & 789,000 & 535,000 \\
Shrimp & 232,000 & 27,800 & 670,000 & 58,300 \\
Marine finfish & 180,000 & 36,000 & 590,000 & 110,600 \\
\hline
\end{tabular}


Table 8 Microalgae applications as aquaculture feeds

\begin{tabular}{llll}
\hline Microalgae species & Types of fish/aquaculture & Growth rate (\%) & References \\
\hline Chlorella spp. & Nile Tilapia & 50 & Badwy et al. (2008) \\
Scenedesmus spp. & & 50 & \\
Dunaliella spp. & Nile Tilapia & $50-75$ & Attalla and Mikhail (2008) \\
Schizochytrium sp. & Channel catfish & 2 & Li et al. (2009) \\
Spirulina & Mekong Giant Catfish & $5-10$ & Tongsiri et al. (2010) \\
Tetrasel missuecica & Sea Bass & $10-20$ & Tulli et al. (2012) \\
Spirulina platensis & Angel fish & $5-20$ & Mahsa et al. (2013) \\
Arthrospira plantesis & Whiteleg Shrimp & $25-75$ & Macias-Sancho et al. (2014) \\
Scenedesmus almeriensis & Gilthead seabream & $12-39$ & Vizcaíno et al. (2014) \\
Entomoneis spp. & Juvenile Atlantic Salmon & 2.5 & Norambuena et al. (2015) \\
\hline
\end{tabular}

(2008) followed by Badwy et al. (2008). Attalla and Mikhail (2008) used Dunaliella spp. as feeds and achieved 50-75\% growth rates for Nile tilapia. Badwy et al. (2008) studied two types of microalgae species known as Chlorella spp. and Scenedesmus spp. The studied reported a growth rate of $50 \%$ for Nile tilapia when microalgae were used as fish feed. The lowest growth rates were reported by Li et al. (2009) for Channel catfish feeding on Schizochytrium sp. (2\%), followed by the growth rate of juvenile Atlantic Salmon feeding on Entomoneis spp. (2.5\%) (Norambuena et al. 2015).

\section{Conclusion}

This review has attempted to give an overview of the potential of microalgae in the phycoremediation of wet market wastewater and slaughterhouse wastewater as well as the use of microalgae in the production of microalgae biomass. It is hoped that the reader can obtain a clearer idea of the characteristics of these types of wastewater and the treatment processes used for these types of wastewater before they are finally discharged into the environment. The potential of wet market wastewater and slaughterhouse wastewater as a production media of microalgae biomass as well as the potential of biomass yields as fish feed have been explored in this paper. Therefore, these aspects need to be investigated further to promote the use of microalgae as aquaculture feed and their role in improving the characteristics and quality of fish feeding on biomass. Microalgae exhibit high effectiveness as an alternative nutrient source due to high levels of proteins, lipids, and carbohydrates. Moreover, the characteristics of wastewater are important for phycoremediation efficiency and biomass production. Wet market wastewater and slaughterhouse wastewater with a high content of total nitrogen and phosphorus are more suitable for algae growth and biomass yield production. Therefore, the phycoremediation process of wet market wastewater and slaughterhouse wastewater shows promise for the future of aquaculture. Currently, common treatment methods aim to reduce the main pollutants from waste such as sewage. However, wet market wastewater and slaughterhouse wastewater are quite different from sewage or other types of industrial wastewater which are rich in pathogens and heavy metals. Therefore, it represents a very good resource for biomass yields. All future research studies should also look into recycling and reusing treated wastewater, so that there will be minimal or zero net sludge generation.

Acknowledgements The authors gratefully acknowledge the Ministry of Higher Education of Malaysia for the research project financial support under fundamental research Grant scheme (FRGS) vot No. 1453. We also thankful to get a support from ORICC UTHM through research grants STG Vot U659 and IGSP Vot U682.

Author contributions MAY was the main researcher. The authors MRMSR, A-GAA, and AHMK have contributed significantly in this paper, collecting and analysing the information, writing, and editing the manuscript and approved the final version.

\section{Compliance with ethical standards}

Availability of data and materials Data sharing not applicable to this article as no data sets were generated or analysed during the current study. 
Conflict of interest The authors declared that they have no conflict of interest.

Open Access This article is distributed under the terms of the Creative Commons Attribution 4.0 International License (http:// creativecommons.org/licenses/by/4.0/), which permits unrestricted use, distribution, and reproduction in any medium, provided you give appropriate credit to the original author(s) and the source, provide a link to the Creative Commons license, and indicate if changes were made.

\section{References}

Abdulrahman NM, Ameen JH (2014) Replacement of fishmeal with microalgae spirulina on common carp weight gain, meat and sensitive composition and survival. Pak J Nut 13(2):93-98

Ajani EK, Orisasona O, Omitoyin BO, Osho EF (2016) Total replacement of fishmeal by soybean meal with or without methionine fortification in the diets of Nile tilapia, Oreochromis niloticus. J Fish Aquat Sci 11:238-243

Ajayan KV, Selvaraju M, Unnikannan P, Sruthi P (2016) Phycoremediation of tannery wastewater using microalgae Scenedesmus species. Int J Phytorem 17(10):1-36. doi:10.1080/15226514.2014.989313

Albalasmeh AA, Berhe AA, Ghezzehei TA (2013) A new method for rapid determination of carbohydrates and total carbon concentrations using UV spectrophotometry. Carbohyd Poly 97:253-261

Al-Darmaki A, Govindrajan L, Talebi S, Al-Rajhi S, Al-Barwani T, Al-Bulashi Z (2012) Cultivation and characterization of microalgae for wastewater treatment. Proceedings of the World Congress on Engineering 2012 vol I. WCE 2012, London, 4-6 July 2012

Al-Gheethi AA, Norli I, Lalung J, Azieda T, Ab. Kadir MO (2013) Reduction of faecal indicators and elimination of pathogens from sewage treated effluents by heat treatment. Cas J Appl Sci Res 2(2):29-45

Al-Gheethi AA, Mohamed RMSR, Afaiz Ab. Rahman M, Mas Rahayu J, Amir HK (2015) Treatment of wastewater from car washes using natural coagulation and filtration system. In: International Conference on Sustainable Environment and Water Research (ICSEWR2015), 25-26 Oct 2015, Johor Baru

AOAC (1995) Animal Feed. Association of Official Analytical Chemists, Chapter 4 in Official Methods of Analysis. 16th edition. AOAC International, Arlington, VI, USA. p 30

Arkronrat W, Deemark P, Oniam V (2016) Growth performance and proximate composition of mixed cultures of marine microalgae (Nannochloropsis sp. \& Tetraselmis sp.) with monocultures. Songklanakarin. J Sci Technol 38(1):1-5

Atiku A, Mohamed RMSR, Al-Gheethi AA, Wurochekke AA, Kassim Amir H (2016) Harvesting microalgae biomass from the phycoremediation process of greywater. Environ Sci Poll Res 23:24624-24641

Attalla RF, Mikhail SK (2008) Effect of replacement of fish meal protein with boiled full fat soybean seeds and dried algae on growth performance, nutrient utilization and some blood parameters of Nile tilapia, Egypt. J Aquat Biol Fish 12(4):41-60

Badwy TM, Ibrahim EM, Zeinhom MM (2008) Partial replacement of fish meal with dried microalga (Chlorella spp. and Scenedesmus spp.) in Nile Tilapia (Oreochromis Niloticus) Diets. In: 8th International Symposium on Tilapia in Aquaculture, pp 801-811

Baharuddin NN, Azizi NS, Sohif HN, Karim WA, Al-Obaidi JR, Basiran MN (2016) Marine microalgae flocculation using plant: the case of Nannochloropsis oculata and Moringa oleifera. Pak J Bot 48(2):831-840

Barbarino E, Lourenco SO (2005) An evaluation of methods for extraction and quantification of protein from marine macro and microalgae. J Appl Phycol 17:447-460

Bazrafshan E, Mostafapour FK, Farzadkia M, Ownagh KA, Mahvi AH (2012) Slaughterhouse wastewater treatment by combined chemical coagulation and electrocoagulation process. PLoS One. doi:10.1371/journal.pone.0040108

Bello YO, Oyedemi DT (2009) Impact of abattoir activities and management in residential neighbourhoods: a case study of Ogbomoso, Nigeria. J Soc Sci 19:121-127

Bligh EG, Dyer WJ (1959) A rapid method of total lipid extraction and purification. Can J Biochem Physiol 37(8):911-917

Bradford MM (1976) A rapid and sensitive method for the quantitation of microgram quantities of protein utilizing the principle of protein dye binding. Anal Biochem 72:248-254

Brown MR (2002) Nutritional value of microalgae for aquaculture. In: Cruz-Suarez LE, Ricque-Marie D, Tapia-Salazar M, Gaxiola-Cortés MG, Simoes N (eds.) Advances in Aquaculture Nutrition VI. Proceedings of the VI International Symposium on Nutrition Aquaculture, Cancun (3-6 Sep 2002)

Budiyono B, Widiasa IN, Johari S, Sunarso S (2011) Study on slaughterhouse waste potency and characteristic for biogas production. Int J Water Res 1(2):4-7

Bustillo-Lecompte CF, Mehrvar M (2015) Slaughterhouse wastewater characteristics, treatment, and management in the meat processing industry: a review on trends and advances. J Environ Manage 161:287-302

Cassidy KO (2011) Evaluating algal growth at different temperatures. Theses and Dissertations-biosystems and agricultural engineering. Paper 3

Chan NW (2006) A Comparative study of water resources usage by households in Georgetown-Malaysia and Pattaya, Thailand. Iran J Environ Health Sci Eng 3(4):223-228

Chen SY, Pan LY, Hong MJ, Lee AC (2012) The effect of temperature on the growth of and ammonia uptake by marine microalgae. Bot Stud 53:125-133

Chisti Y (2007) Biodiesel from microalgae. Biotechnol Adv 25:294-306

Cho SC, Choi WY, Oh SH, Lee CG, Seo YC, Kim JS, Song CH, Kim GV, Lee SY, Kang DH, Lee HY (2012) enhancement of lipid extraction from marine microalga, scenedesmus associated with high-pressure homogenization process. J Biomed Biotechnol. doi:10.1155/2012/359432 
Choix FJ, De-Bashana LE, Bashan Y (2012) Enhanced accumulation of starch and total carbohydrates in alginate-immobilized Chlorella spp. induced by Azospirillum brasilense: I. Autotrophic conditions. J Enzy Microb Technol 51:294-299

Craig S (2009) Understanding fish nutrition, feeds and feeding. Virginia cooperative extension, Virginia Tech, Virginia State University. Publication no 420-256.1-4. https://pubs.ext.vt.edu/420/420-256/420-256.html. Accessed 11 March 2017

Dayananda C, Kumudha A, Sarada R, Ravishankar GA (2010) Isolation, characterization and outdoor cultivation of green microalgae Botryococcus sp. J Sci Res Essays 5(17):2497-2505

Derrien A, Coiffard LJM, Coiffard C, Roeck-Holtzhauer YD (1998) Free amino acid analysis of five microalgae. J Appl Phycol 10:131-134

Focardi S, Corsi I, Franchi E (2005) Safety issues and sustainable development of European aquaculture: new tools for environmentally sound aquaculture. Aquacult Int 13:3-17

Folch J, Lees M, Stanley GHS (1957) A simple method for the isolation and purification of total lipides from animal tissues. J Biol Chem 226:497-509

Gao F, Li C, Yang ZH, Zeng GM, Feng LJ, Liu JZ, Liu M, Cai HW (2016) Continuous microalgae cultivation in aquaculture wastewater by a membrane photobioreactor for biomass production and nutrients removal. Ecol Eng 92:55-61

Golueke CG, Oswald WJ, Gotaas HB (1957) Anaerobic digestion of algae. Appl Environ Microbiol 5(1):47-55

Gour RS, Chawla A, Singh H, Chauhan RS, Kant A (2016) Characterization and screening of native Scenedesmus sp. isolates suitable for biofuel feedstock. PLoS One 11(5):1-16. doi:10.1371/journal.pone.0155321

Grammes F, Reveco FE, Romarheim OH, Landsverk T, Mydland LT, Øverland M (2013) Candida utilis and Chlorella vulgaris Counteract Intestinal Inflammation in Atlantic Salmon (Salmo salar L.). PLoS ONE 8(12):e83213. doi:10.1371/journal.pone. 0083213

Griffiths MJ, Dicks RG, Richardson C, Harrison STL (2011) Advantages and challenges of microalgae as a source of oil for biodiesel. Biodiesel - feedstocks and processing technologies, In Tech, pp 1-25. http://www.intechopen.com/books/ biodiesel-feedstocks-and-processing-technologies/advantages-and-challenges-of-microalgae-as-a-source-of-oil-for-biodiesel. Accessed 13 July 2016

Guedes AC, Malcata FX (2012) Nutritional value and uses of microalgae in aquaculture, aquaculture. In: Dr. Zainal Muchlisin (ed.), ISBN: 978-953-307-974-5, InTech. http://www.intechopen.com/books/aquaculture/nutritional-value-and-uses-ofmicroalgae-in-aquaculture

Hakalin NLS, Paz AP, Aranda DAG, Moraes LMP (2014) Enhancement of cell growth and lipid content of a freshwater microalga Scenedesmus sp. by optimizing nitrogen, phosphorus and vitamin concentrations for biodiesel production. Nat Sci 6:1044-1054

Hannon M, Gimpel J, Tran M, Rasala B, Mayfield S (2010) Biofuels from algae:challenges and potential. Biofuels 1(5):763-784

Hashim R, Saat MAM (1992) The utilization of seaweed meals as binding agents in pelleted feeds for snakehead (Channa striatus) fry and their effects on growth. Aquaculture 108(3-4):299-308

Huang Y, Chen M, Liu D (2008) Effect of nitrogen, phosphorus, light formation and disappearance and water temperature on the of blue-green algae bloom. J Northwest Sci Technol Univ Agric For (Nature Science Edition) 36(9):93-100

Islam MS, Wahab MA, Tanaka M (2004) Seed supply for coastal brackish water shrimp farming: environmental impacts and sustainability. Mar Pollut Bull 48(1-2):7-11

Jais NM, Mohamed RMSR, Apandi WAWM, Peralta HMM (2015) Removal of nutrients and selected heavy metals in wet market wastewater by using microalgae Scenedesmus sp. Appl Mech Mater 773-774:1210-1214

Jais NM, Mohamed RMSR, Al-Gheethi AA, Hashim Amir (2017) Dual role of phycoremediation of wet market wastewater for nutrients and heavy metals removal and microalgae biomass production. Clean Technol Environ Policy 19(1):37-52

Jena J, Nayak M, Panda HS, Pradhan N, Sarika C, Panda PK, Rao BVSK, Prasad RBN, Sukla LB (2012) Microalgae of Odisha Coast as a potential source of biodiesel production. World Environ 2(1):11-16

Joseph CW, Raymond PG, John RB (1988) Photobioreactor design: mixing, carbon utilization, and oxygen accumulation. Biotechnol Bioeng 31:336-344

King JW (2002) Supercritical fluid technology for lipid extraction, fractionation and reactions. In: Kuo TM, Gardner H (eds) Lipid biotechnology. Marcel Dekker Inc., New York, pp 663-687

Kumar RR, Rao PH, Arumugam M (2015) Lipid extraction methods from microalgae: a comprehensive review. Front Energy Res. doi:10.3389/fenrg.2014.00061

Kumar M, Kulshreshtha J, Singh GP (2011) Growth and biopigment accumulation of cyanobacterium Spirulina platensis at different light intensities and temperature. Brazilian J Microbiol 42:1128-1135

Kundu P, Debsarkar A, Mukherjee S (2013) Treatment of slaughter house wastewater in a sequencing batch reactor performance evaluation and biodegradation kinetics. Biomed Res Int. doi:10.1155/2013/134872

Kwarciak-Kozłowska A, Sławik-Dembiczak L, Bańka B (2014) Phycoremediation of wastewater: heavy metal and nutrient removal processes. Environ Prot Nat Resour 25(4):51-54

Lee JY, Jun S, Ahn CY, Oh HM (2010) Comparison of several methods for effective lipid extraction from microalgae. J Bioresour Technol 101:75-77

Lee KE, Mokhtar M, Mohd Hanafiah M, Abdul Halim A, Badusah J (2015) Rainwater harvesting as an alternative water resource in Malaysia: potential, policies and development. J Clean Prod. doi:10.1016/j.jclepro.2016.03.060

Li JP, Healy MG, Zhan XM, Rodgers M (2008) Nutrient removal from slaughterhouse wastewater in an intermittently aerated sequencing batch reactor. Biores Technol 99(16):7644-7650

Li MH, Robinson EH, Tucker CS, Manning BB, Khoo L (2009) Effects of dried algae Schizochytrium sp., a rich source of docosahexaenoic acid, on growth, fatty acid composition, and sensory quality of channel catfish Ictalurus punctatus. Aquaculture 292:232-236

Liu C, Jin X, Sun L (2005) Effects of pH oil growth and species changes of algae in freshwater. J Agro Environ Sci 24(2):294-298 
Lopez CVG, Garcia MDCC, Fernandez FGA, Bustos CS, Chisti Y, Sevilla JMF (2010) Protein Measurements of microalgal and cynobacterial biomass. Biores Technol 101:7587-7591

Lowry OH, Rosebrough NJ, Farr AL, Randall RJ (1951) Protein measurement with the Folin phenol reagent. J Biol Chem 193:265-275

Macias-Sancho J, Poersch LH, Bauer W, Romano LA, Wasielesky W, Tesser MB (2014) Fishmeal substitution with Arthrospira (Spirulina platensis) in a practical diet for Litopenaeus vannamei: effects on growth and immunological parameters. Aquaculture 426-427:120-125

Mahsa B, Moosavi Javadi, Montajami Salar (2013) Assesment the effect of Spirulina plantesis feed on growth performance and survival rate in Angel Fish (Pterophyllum scalare). J Fish Int 8(3-6):74-77

Makareviciene V, Andrulevičiūtė V, Skorupskaitė V, Kasperovičienė J (2011) Cultivation of microalgae Chlorella sp. and Scenedesmus sp. as a potentional biofuel feedstock. Environ Res Eng Manag 3(57):21-27

Masse DI, Masse L (2000) Treatment of slaughterhouse wastewater in anaerobic sequencing batch reactors. Can Agr Eng 42(3):131-137

Mata TM, Martins AA, Caetano NS (2010) Microalgae for biodiesel production and other applications: a review. Renew Sustain Energy Rev 14(1):217-232

Mente E, Pierce GJ, Santos MB, Neolitou C (2006) Effect of feed and feeding in the culture of salmonids on the marine aquatic environment: a synthesis for European aquaculture. Aquacult Int 14:499-522

Michels MH, Vaskoska M, Vermuë MH, Wijffels RH (2014) Growth of Tetraselmis suecica in a tubular photobioreactor on wastewater from a fish farm. Water Res 65:290-296

Minhas AK, Hodgson P, Barrow CJ, Adholeya A (2016) A review on the assessment of stress conditions for simultaneous production of microalgal lipids and carotenoids. Front Microbiol 7:546. doi:10.3389/fmicb.2016.00546

Mohamed RMSR, Al-Gheethi AA, Jackson AM, Amir HK (2016) Multi component filters for domestic greywater treatment in village houses. J Am Water Works Assoc 108(7):405-414

Mulbry W, Kondrad S, Pizarro C, Kebede-Westhead E (2008) Treatment of dairy manure effluent using freshwater algae: algal productivity and recovery of manure nutrients using pilot-scale algal turf scrubbers. Bioresour Technol 99:8137-8142

Murphy CD, Moore RM, White RL (2000) Peroxidases from marine microalgae. J Appl Phycol 12:507-513

Nandeshwar SN, Satpute GD (2014) Green technical methods for treatment of waste water using microalgae and its application in the management of natural water resources-a review. Curr World Environ. doi:10.12944/CWE.9.3.34

Noori MdT, Ghangrekar MM, Mukherjee CK (2016) V2O5 microflower decorated cathode for enhancing power generation in aircathode microbial fuel cell treating fish market wastewater. Int J Hydrog Energy 41:3638-3645

Norambuena F, Hermon K, Skrzypczyk V, Emery JA, Sharon Y, Beard A, Turchini GM (2015) Algae in fish feed: performances and fatty acid metabolism in juvenile atlantic salmon. PloS One 10(4):e0124042

Omar D, Salim MR, Salmiati (2016) Nutrient removal of greywater from wet market using sequence batch reactor. Malaysia J Anal Sci 20(1):142-148

Pahazri F, Mohamed RMS, Al-Gheethi AA, Hashim Amir (2016) Production and harvesting of microalgae biomass from wastewater, a critical review. Environ Technol Rev 5(1):39-56

Panserat S, Kaushik S (2002) Nutritional regulation of hepatic glucose metabolism in fish: example of a poor user of dietary carbohydrates, the rainbow trout. Prod Anim 15:109-117

Peiber S, Schober S, Mittelbach M (2012) Pressurized fluid extraction of polyunsaturated fatty acids from the microalga Nannochloropsis oculata. Biomass Bioenerg 47:474-482

Pérez-Pazos JV, Fernández-Izquierdo P (2011) Synthesis of neutral lipids in Chlorella sp. under different light and carbonate conditions. Sci Technol Future 4(4):47-57

Prommuak C, Pavasant P, Quitain AT, Goto M, Shotipruk A (2012) Microalgal lipid extraction and evaluation of single-step biodiesel production. Eng J 16(5):157-166

Pulz O, Gross W (2004) Valuable products from biotechnology of microalgae. Appl Microbiol Biotechnol 65:635-648

Radhakrishna S, Saravana BP, Seenivasan C, Muralisankar T (2015) Effect of dietary replacement of fishmeal with Chlorella vulgaris on growth performance, energy utilization and digestive enzymes in Macrobrachium rosenbergii postlarvae. Int $\mathrm{J}$ Fish Aquac 7(5):62-70

Rahimi Y, Torabian A, Mehrdadi N, Shahmoradi B (2011) Simultaneous nitrification-denitrification and phosphorus removal in a fixed bed sequencing batch reactor (FBSBR). J Haz Mat 185(2-3):852-857

Rai MP, Gautom T, Sharma N (2015) Effect of salinity, pH, light intensity on growth and lipid production of microalgae for bioenergy application. J Biol Sci 15(4):260-267

Rajakumar R, Meenambal T, Banu TR, Yeom IT (2011) Treatment of poultry slaughterhouse wastewater in up flow anaerobic filter under low up flow velocity. Int J Environ Sci Tech 8(1):149-158

Rajamani S, Hilda A (1987) Plate assay to screen fungi for proteolytic activity. Curr Sci 56:1179-1181

Ramaraj R, Tsai DDW, Chen PH (2015) Detention time study of algal biomass production with natural water medium. Chiang Mai J Sci. 42(3):549-559

Ras M, Steyer JP, Bernard O (2013) Temperature effect on microalgae: a crucial factor for outdoor production. Rev Enviro Sci BioTechnol 12(2):153-164

Rasala B, Mayfield S (2015) Photosynthetic biomanufacturing in green algae; production of recombinant proteins for industrial, nutritional, and medical uses. Photosynth Res 123:227-239

Ren TT (2014) Primary factors affecting growth of microalgae optimal light exposure duration and frequency. Graduate Theses and Dissertations. Paper 13793. Iowa State University, Ames

Riano B, Blanco S, Becares E, Garcia-Gonzalez MC (2016) Bioremediation and biomass harvesting of anaerobic digested cheese whey in microalgal-based systems for lipid production. Ecol Eng 97:40-45 
Rodriguez JRB, Reina GG, Rodriguez JJS (1997) Determination of free amino acids in microalgae by high performance liquid chromatography using pre-column fluorescence derivatization. Biomed Chromatogr 11:335-336

Roy SS, Chaudhuri A, Mukherjee S, HomeChauduri S, Pal R (2011) composite algal supplementation in nutrition of Oreochromis mossambicus. J Algal Biom Util 2(1):10-20

Ruiz I, Veiga MC, de Santiago P, Blfizquez R (1997) Treatment of slaughterhouse wastewater in a UASB reactor and an anaerobic filter. Biores Technol 60(3):251-258

Rulong L, Wenxuan C, Bingpeng X, Xiurong K (2012) Optimization of extraction conditions for increasing microalgal lipid yield by using accelerated solvent extraction method (ASE) based on the orthogonal array design. InTech, pp 21-38

Santos CPE, Robbins DMRS (2004) Low-cost innovative solutions for treating public market wastewater in the philippines: deploying hybrid anaerobic/aerobic coco peat filtration systems. PADCO, Makati

Sarkar SK, Bhattacharya AK (2003) Conservation of biodiversity of coastal resources of Sundarbans, Northeast India: and integrated approach through environmental education. Marine Pollution Bulletin 47:260-264

Satpal, Khambete AK (2016) Waste water treatment using micro-algae—a review paper. Int J Eng Technol Manag Appl Sci. 4(2):188-192. http://www.ijetmas.com

Sazdanoff N (2006) Modelling and simulation of the algae to biodiesel fuel cycle. Honour's thesis, Ohio State University, Columbus

Schwenzfeier A, Wierenga AP, Gruppen H (2011) Isolation and characterization of soluble protein from the green microalgae Tetraselmis sp. J Bioresour Technol 102:9121-9127

Sen M, Alp MT, Sonmez F, Kocer MAT, Canpolat O (2013) Relationship of algae to water pollution and waste water treatment. Elshorbagy W (ed.) Water treatment, InTech, doi:10.5772/51927

Sethupathy AV, Subramanian A, Manikandan R (2015) Phyco-remediation of sewage waste water by using micro-algal strains. Int J Eng Innov Res 4(2):300-302

Sheehan J, Dunahay T, Benemann J, Roessler P (1998) A look back at the US Department of Energy's Aquatic Species Program: biodiesel from algae. In: Close-out report. National Renewable Energy Lab, Department of Energy, Golden, Colorado, Report number NREL/TP-580-24190

Singh J, Gu S (2010) Commercialization potential of microalgae for biofuels production. Renew Sustain Energy Rev $14: 2586-2610$

Sirakov I, Velichkova K, Stoyanova S, Staykov Y (2015) The importance of microalgae for aquaculture industry. Review. Int J Fish Stud 2(4):81-84

Skarka J (2012) Microalgae biomass potential in europe: land availability as a key issue. Technol Assess Theory Pract Des 21(1):72-80

Smith PK, Krohn RI, Hermanson GT (1985) Measurement of protein using bicinchoninic acid. Anal Biochem 150:76-85

Solovchenko A, Verschoor AM, Jablonowski ND, Nedbal L (2016) Phosphorus from wastewater to crops: an alternative path invilving microalgae. Biotechnol Adv 34:550-564

Sombatsompop K, Songpim A, Reabroi S, Inkongngam P (2011) A comparative study of sequencing batch reactor and moving bed sequencing batch reactor for piggery wastewater treatment. Maejo Int J Sci Technol 5(2):191-203

Tacon AGJ, Hasan MR, Subasinghe RP (2006) Use of fishery resources as feed inputs to aquaculture development: trends and policy implications FAO fisheries circular No. 1018. FAO, Rome, p 99

Takemura N, Iwkume T, Rusuno M (1985) Photosynthesis and primary production of Microcystis agruginosa in Lake Kasumigaura. J Plankton Res 7(3):303-312

Tan X, Kong F, Yu Y (2009) Effects of enhanced temperature on algae recruitment and phytoplankton community succession. China Environ Sci 29(6):578-582

Tartiel MB (2005) Physiological studies on some green algae. Ph.D. thesis, Faculty of Agriculture, Cairo University, Egypt

Tongsiri S, Mang-amphan K, Peerapornpisal Y (2010) Effect of replacing fishmeal with spirulina on growth, carcass composition and pigment of the Mekong Giant Catfish. Asian J Agr Sci 2(3):106-110

Tulli F, Chini Zittelli G, Giorgi G, Poli BM, Tibaldi E, Tredici MR (2012) On growth, feed utilization, and fillet composition of european sea bass juveniles fed organic diets. J Aquat Food Prod Technol 21(3):188-197

Um BH, Kim YS (2009) Review: a chance for Korea to advance algal-biodiesel technology. J Ind Eng Chem 15:1-7

Vizcaíno J, López G, Sáez MI, Jiménez J, Barros A, Hidalgo L (2014) Alarcón FJ (2015) Effects of the microalga Scenedesmus almeriensis as fishmeal alternative in diets for gilthead sea bream, Sparus aurata, juveniles. Aquaculture 431:34-43

Wurochekke AA, Mohamed RMS, Al-Gheethi AA, Amir HM, Matias-Peralta HM (2016) Household greywater treatment methods using natural materials and their hybrid system. J Water Health 14:914-928 (Online)

Xin L, Ying HH, Ping ZY (2011) Growth and lipid accumulation of a freshwater microalga Scenedesmus sp. under different cultivation temperature. Biores Technol 102:3098-3102

Zang C, Huang S, Wu M (2011) Comparison of relationships between pH, dissolved oxygen and Chlorophyll $a$ for aquaculture and nonaquaculture waters. Water Air Soil Poll 219(1-4):157-174

Zhang Q, Hong Y (2014) Comparison of growth and lipid accumulation properties of two oleaginous microalgae under different nutrient conditions. Front Environ Sci Eng 8(5):703-709

Zulkifli AR, Roshadah H, Tunku Khalkausar TF (2011) Control of water pollution from non-industrial premises. Department of Environment, Malaysia 